\title{
Translation of Cross-Clausal Repetition: A Case Study of Pride and Prejudice
}

\author{
LI Xiu-li \\ China University of Political Science and Law, Beijing, China
}

\begin{abstract}
Repetition plays a very important role in keeping a discourse cohesive and coherent. This research adopts the principle of faithfulness in the translation of literary works and examines 10 discourses where cross-clausal repetition of words occurs in Austen's Pride and Prejudice. The research draws the conclusion that the translators in general failed to pay enough attention to the cohesive functions of cross-clausal repetition in their translation and that the rates of satisfying and acceptable renderings of repeated words are low, being $8.3 \%$ and $18.3 \%$ respectively. Besides, alternative and better ways of rendering those repeated words examined in the paper are provided when the need arises. The research extends the scope of repetition of part of a clause illustrated by ZHU Yong-sheng and points out that repetition serves new functions of refuting and contrasting.
\end{abstract}

Keywords: repetition, cross-clausal cohesion, Pride and Prejudice, translation

\section{Introduction}

Pride and Prejudice is one of the greatest novels in the history of English literature and has been translated into Chinese by a number of translators over a period of more than half a century from the 1950s to present day. The Chinese versions of the novel have been well read by Chinese readers. However, in my study of the English-Chinese translation of the novel, I have noticed some very common mistakes made by translators and nice renderings that sometimes occur regarding repeated words in the English version of the novel. Repetition is recognized both as a cohesive and rhetorical device. By analyzing and comparing the renderings of some repeated words beyond clauses by Chinese translators of the novel, this paper intends to find out why the inappropriate renderings of the repeated words fail to fulfill the functions of repetition, and what techniques the translators used to try to translate some of the words nicely. The research will also provide proper ways of translating these words so that the cohesive and narrative functions of repeated words can be fully fulfilled in the Chinese versions of the novel. Finally, the paper intends to shed some light on whether there has been improvement in the translation of the novel over the years.

It needs to be mentioned that the Chinese versions of the novel chosen by the author were published in Mainland China and Taiwan over a period of more than 50 years from 1955 to 2011 . They are the works of WANG Ke-yi, ZHANG Ling and ZHANG Yang, SUN Zhi-li, FANG Hua-wen, LIU Pei-fang and DENG Sheng-ming, and LE Xuan. The versions of WANG, ZHANG, and ZHANG and SUN used in this research first came out in 1955, 1993, and 2000 respectively. WANG Ke-yi, ZHANG Ling, SUN Zhi-li, and LIU Pei-fang are regarded as established translators in Mainland China whereas LE Xuan is a writer, translator, and professor

LI Xiu-li, Associate Professor, M.A., School of Foreign Languages, China University of Political Science and Law. 
at Ningbo University and LIU is a productive translator from Taiwan.

\section{Literature Review}

The functions of repetition have been well studied by scholars at every level of discourse from sound and sense to plot and to theme and genre. Anderson (1994) and Kirby (2009) examine the narrative functions of repetition in the Bible. Kirby illustrates seven narrative functions of repetition proposed by Anderson. Halliday and Hasan (2001), HU Zhuang-lin (1984), ZHANG De-lu and LIU Ru-shan (2003) and ZHU Yong-sheng, ZHENG Li-xin, and MIAO Xing-wei (2001) analyze how repeated words help to make a cohesive or coherent text. In his analysis of the cohesive and coherent functions of repetition, HU Zhuang-lin (1984, pp. 115-117) divides repetition into two kinds: repetition of words and repetition of structure. HU argues that the repetition of words serves the function of establishing the topic or theme of a discourse or keeping a conversation going by joining in or turn taking while the repetition of structure fulfills the function of producing emphasis, adding new information, or preparing for the use of parallelism. ZHU Yong-sheng (2001, pp. 110-121) classifies repetition into repetition of a word and repetition of a clause or part of a clause. ZHU points out six cohesive functions of cross-clausal repetition. According to ZHU, repetition serves the function of emphasizing the afore-mentioned unit, imitating what another person has said, agreeing with what others have said, requesting a confirmation of what has been said, bringing back an afore-mentioned topic, or of uniting the content of a text.

Studies have also been done by Chinese scholars on the translation of repeated words. JING Su-rong (2010) examines two frequently repeated words in Bacon's "Of Innovations" and points out that these two words have the rhetorical function of highlighting the theme of the essay and each of them should have been rendered as one Chinese equivalent rather than several in each of the four Chinese versions of the article examined in her paper. LUO Lin-quan (2007) analyzes the cohesive functions and translation of cross-clausal reiteration of words (their synonyms, hyponyms, or hypernyms included) and points out that sometimes cross-clausal reiteration is difficult to recognize owing to the distance between the repeated words. ZHOU Tian (2007) argues that flexibility shall be allowed on certain occasions though theoretically repeated words should be kept the same way in a translated work as they are in the original. LI Xiu-li (2016) examines the translation of the word "pride" in Jane Austen's Pride and Prejudice.

\section{Scope, Method, and Innovation of the Research}

The paper adopts ZHU Yong-sheng's idea of dividing repetition into two categories: intra-clausal repetition and cross-clausal repetition and focuses its attention exclusively on cross-clausal repetition. However, since the focus of my research is more on the translation of repeated words than on their functions, it has two distinct features. First, this paper expands the scope of repeated words to include derivational cognates, namely words of the same origin formed by the word-formation process of derivation. Although the co-existence of a given English word and its cognate(s) in a short sentence has been recognized as polyptoton by the world of rhetoric (Burton, 2007) and studied by Chinese scholars like LIU Ying-kai and ZHANG Zhen-he (1998), and LI Chang-bao (2004), the co-existence of a given word and its cognate(s) in distant proximity is excluded from the figures of repetition. Luckily, it has been acknowledged as having cohesive effect by linguists such as $\mathrm{HU}$ Zhang-lin (1984, pp. 112, 116) and ZHU Yong-sheng (2001, p. 110). Secondly, although ZHU defines language unit as a word, part of a clause or a clause, his scope of part of a clause is a little too narrow. His research fails to provide an explanation for some discourses in which partial repetition occurs. For example, in 
chapter six of Pride and Prejudice when Mrs. Bennett says to Elizabeth "You will not be fit to be seen when you get there", Elizabeth replies "I shall be very fit to see Jane, which is all I want". Clearly, repetition of "fit to be seen"/"fit to see" is used by Elizabeth to refute. Take another example. After leaving Rosings Maria says "How much I shall have to tell!" and Elizabeth privately adds "And how much I shall have to conceal". In this discourse "how much I shall have to" is used together with "conceal" to make a contrast. ZHU's study of cross-clausal cohesion focuses on full repetition (repetition of a clause), and partial repetition like "how much I shall have to" in one of the above examples is left out. Though it is true that the function of refutation or contrast cannot be fulfilled without words opposite in meaning, it is also true that partial repetition is used when we refute or make a contrast. When it comes to translation, it is more convenient to enlarge the scope of partial repetition. By doing so, new functions of repetition can be added to the functions provided by ZHU. Kirby (2009, p. 172) illustrates that repetition has the narrative function of building patterns of association or drawing contrast. This function can be adapted to explain new cohesive functions of repetition. In this paper, HU Zhuang-lin's theory of the functions of repetition will also be adopted.

By repeated words, the paper means both repetition of a single word in a clause and repetition of a cluster of words (part of a clause). The examples to be analyzed in this paper are mainly taken randomly from the third part of the novel.

It has been acknowledged by scholars that the principle to follow in the translation of great literary works is that a translated work should be faithful to the original work both in form and in content (XU, 2012) and adaptation is allowed only when an equivalent form in the target language cannot be found. According to MAO Dun (as cited in XU, 2012), good translation is neither word for word translation nor unrestricted free translation where the original sentence structure and word choice are unnecessarily violated. This principle that form weighs as much as content will be adopted in my evaluation of the renderings of repeated words. In my research, content refers not only to the literal meaning of the repeated words but also the functions fulfilled by repetition of the words. In this sense, form and content are inseparable for the form of repetition fulfills cohesive functions.

\section{A Case Study}

Repetition of words does not mean redundant repetition of old information, but rather enables new information to be added in a discourse. New information is added to serve several functions. Cross-clausal repetition is sometimes used to compare or contrast, draw the reader's attention, and to emphasize. In discourses like dialogues, repetition can be employed to refute or confirm. In the following part, examples are given to show how insufficient translation of repeated words damages the cohesive functions of repetition. To save space, for each example discourse only one Chinese rendition is fully presented when the need arises, and all six renditions of repeated words in the Chinese versions of the novel are shown in tables. The underscores and superscripts in the examples are mine.

\section{Cross-Clausal Repetition of Words Used in Non-dialogues}

Example (1)

... and how Lydia could ever have attached him had appeared incomprehensible. But now it was all too natural. For such an attachment as this she might have sufficient charms;... (Austen, 1949, p. 232)

而莉迪亚怎么会让他看上眼....... 像这种儿女之情, 莉迪亚有那般魅力也就足够了。(SUN, 1999, p. 252) 
Table 1

Translation of Repeated Word Used to Add New Information

\begin{tabular}{lll}
\hline & attached (him) & (such an) attachment (as this) \\
\hline FANG & (莉迪亚怎么会让他)着迷, & (像这样轻浪的) 情爱 \\
LIU \& DENG & (莉蒂亚对他有什么)吸引力 & (威肯对她)倾心 \\
LE & (丽迪亚怎么会) 爱上(他) & (像这一类的)苟合 \\
WANG & (丽迪雅又怎么会)爱上他 & (像这一类的)苟合 \\
SUN & (莉迪亚怎么会让他)看上眼 & (像这种) 儿女之情 \\
ZHANG \& ZHANG & 莉迪亚又怎么能够吸引他呢 & 像这样一种男女之情 \\
\hline
\end{tabular}

In this example, "attachment" is used to add new information to the relationship between Lydia and Wickham. It can be seen from the table above that all the renderings are far from being satisfying. Firstly, "attachment" refers to the attraction Wickham feels towards Lydia and has the quality of its verbal cognate “attach”, involving an object and subject and a direction of action. Expressions like “像这一类的苟合”, “像这 种儿女之情”, and “像这样一种男女之情” in the renderings of LE, WANG, SUN, and ZHANG and ZHANG sound more like mutual affection. Secondly, "such an attachment as this" is an expression used to emphasize and specify and in the Chinese translation this function can be maintained by adding dots under “这样”. The renderings of SUN and LIU and DENG fail to maintain this function. Thirdly, Elizabeth is shocked and pained by the relationship between Lydia and Wickham but does not use explicitly despising terms to describe it. "轻 浪” and “荷合” in the renderings of FANG, LE, and WANG are clearly despising terms.

In all the six renderings, the form of repetition is violated and the subtle feature of the original language is lost. In fact, the form of repetition can be kept in the Chinese version if more effort is exerted. See my renderings below.

莉迪亚怎会让他动情...... 让他动这样一种情, 莉迪亚的鬼力也许就足够了。

莉迪亚又怎么能够吸引他呢?...... 像这样一种吸引, 莉迪亚的魅力也许就足够了。

莉迪亚怎会让他产生男女之情? ...... 像这样一种男女之情, 莉迪亚的魅力也许就足够了。

Example (2)

They stood a little aloof while he was talking to their niece, who, astonished ${ }^{1}$ and confused, scarcely dared lift her eyes to his face, and knew not what answer she returned to his civil enquiries after her family. (Austen, 1949, p. 209)

Whilst wandering on in this slow manner, they were again surprised, and Elizabeth's astonishment ${ }^{2}$ was quite equal to what it had been at first... Elizabeth, however $\underline{\text { astonished }}^{3}$, was at least more prepared for an interview than before... (Austen, 1949, p. 211)

……而伊丽莎白又惊慌又迷乱。(Fang, 2011, p. 229)

……而伊丽莎白的惊愕程度一点不次于方才见到他时...... 伊丽莎白虽然吃惊不小, 但起码不至于像上次见面 时那样措手不及。(FANG, 2011, p. 231)

Table 2

Translation of Repeated Word Used to Compare

\begin{tabular}{|c|c|c|c|c|c|c|}
\hline & FANG & LIU \& DENG & LE & WANG & SUN & ZHANG \& ZHANG \\
\hline astonished $^{1}$ & 惊慌 & 惊讶 & 惊 (慌) & 柁异 & （又) 惊 (又慌) & 惊诧 \\
\hline astonishment $^{2}$ & 惊愕 & 吓了一跳 & 惊讶 & 柁异 & 惊讶 & 大为惊讶 \\
\hline astonished $^{3}$ & 吃惊不小 & 满心惊讶 & 惊讶 & 柁异 & 十分惊奇 & 大感惊讶 \\
\hline (gardener's) surprise & 诧异 & 惊讶 & 惊讶 & 惊奇万状 & 惊奇 & 惊讶 \\
\hline
\end{tabular}


Here in Example (2) "astonished" (its cognate "astonishment" also counts) is used three times to compare Elizabeth's first-time and second-time reactions towards meeting Darcy unexpectedly. The reactions are the same: great surprise. In the six Chinese versions of the novel, however, only WANG's version strictly sticks to the same rendering of "astonished" through the whole discourse and in each of the other five versions Chinese synonyms are used. The problem with synonyms is that synonyms either have slightly different meanings or vary in force/intensity and shall be used only when absolutely necessary in the translation of repeated words. The translators should have been more careful so that the same reactions could be conveyed in the Chinese version. WANG's version has one defect though. In the English version of the novel, Elizabeth's "astonishment" is much greater than the "surprise" felt by the gardener upon beholding his unexpected master. In WANG's version, however, the opposite is made possible for “surprise” is translated as “惊奇万状”. This defect exists in some of the other versions. Therefore, in the translation of repetition over extended textual space translators need to be very careful and put the repeated word into a larger context instead of the immediate context in which the word occurs.

Example (3)

“...How much I shall have to tell!"

Elizabeth privately added, “And how much I shall have to conceal”. (Austen, 1949, p. 183)

Table 3

Translation of Repeated Words Used to Contrast

\begin{tabular}{|l|l|l|}
\hline FANG & 要讲的事情真是太多了! & 可我要隐瞒的事情也着实不少 \\
\hline LIU \& DENG & 我可有一堆事可说了! & 我可有一堆事要瞒了! \\
\hline LE & 我回家后有多少事情需要说啊! & 但是我要隐瞒多少事情啊! \\
\hline WANG & 我回去有多少事要讲啊! & 可是我回去有多少事要瞒啊! \\
\hline SUN & 我回去有多少事要讲啊! & 可我有多少事要隐瞒啊! \\
\hline ZHANG \& ZHANG & 我要讲的事情该有多少呀 & 可是我要隐瞒的事情该有多少呀! \\
\hline
\end{tabular}

Here in this example Elizabeth draws a contrast between what she and Maria are going to do after arriving home, and the contrast is made sharper by the fact that "tell" rhymes with "conceal". Of the six renderings of the discourse, only the ones by FANG and LE fail to fully express the strong contrast conveyed by this repetition by changing the word choice or the word order of the original discourse. However, there is still room for improvement for the other four renderings. In the original version of Elizabeth's utterance, "and" is used to indicate a slight contrast and should be translated as “但” or “而” instead of “但是”, which conveys a strong contrast and is not conversational enough. The main contrast of the original discourse lies not in "and" but in the other words of Elizabeth's utterance. Beside, “讲” contrasts better with “瞒” rather than “隐瞒”. A better rendering of the discourse is as follows:

“......我回去有多少事要讲啊!”

“可我回去有多少事要瞒啊!”

Example (4)

But whether she were violently set against the match, or violently delighted with it, it was certain that her manner would be equally ill adapted to do credit to her sense; and she could no more bear that Mr. Darcy should hear the first raptures of her joy, than the first vehemence of her disapprobation. (Austen, 1949, p. 315) 
Table 4

Translation of Repeated Words Used to Catch the Reader's Attention, Emphasize, Compare and Contrast.

\begin{tabular}{|c|c|c|c|c|c|c|}
\hline & FANG & LIU \& DENG & LE & WANG & SUN & ZHANG \& ZHANG \\
\hline violently set against & 坚决反对 & 暴跳如雷地拒绝 & 极力反对 & 坚决反对 & 极力反对 & 激烈地表示反对 \\
\hline $\begin{array}{l}\text { violently delighted } \\
\text { with }\end{array}$ & 欣喜若狂 & 欣喜欲狂地接受 & 满心欢喜地接 & 欣喜若狂 & 极为满意 & 狂喜地表示赞同 \\
\hline $\begin{array}{l}\text { first raptures of her } \\
\text { joy }\end{array}$ & $\begin{array}{l}\text { 欢天喜地 } \\
\text { 的赞成 }\end{array}$ & $\begin{array}{l}\text { 此事无论成或不 } \\
\text { 成, 达西都得面 } \\
\text { 对难堪的莬境 }\end{array}$ & $\begin{array}{l}\text { (听到) 欢天喜 } \\
\text { 地的赞成 }\end{array}$ & $\begin{array}{l}\text { 欣喜欲狂地 } \\
\text { 表示赞成 }\end{array}$ & $\begin{array}{l}\text { 欢天喜地地表 } \\
\text { 示赞成 }\end{array}$ & 情绪激烈地表示反对 \\
\hline $\begin{array}{l}\text { first vehemence of } \\
\text { her disapprobation }\end{array}$ & $\begin{array}{l}\text { 气势汹汹 } \\
\text { 的反对 }\end{array}$ & $\begin{array}{l}\text { 此事无论成或不 } \\
\text { 成, 达西都得面 } \\
\text { 对难堪的窘境 }\end{array}$ & $\begin{array}{l}\text { (看到) 她第一 } \\
\text { 个义愤填膺地 } \\
\text { 出来反对 }\end{array}$ & $\begin{array}{l}\text { 义愤填胸地 } \\
\text { 表示反对 }\end{array}$ & $\begin{array}{l}\text { 气势汹汹地表 } \\
\text { 示反对 }\end{array}$ & 兴高采烈地表示赞成 \\
\hline
\end{tabular}

Here in this example several functions are fulfilled by repetition. Austen uses the same structures to make a contrast and comparison between Mrs. Bennet's potential sentiments towards the marriage. The repetition of "violently" catches the reader's attention, indicates the same extent of Mrs. Bennet's possible reactions, and emphasizes Mrs. Bennet's tendency to show her feelings and attitudes in an unrestrained and insensible manner. Besides, the repetition of "first", together with other words in the noun structure, forms a comparison and contrast at the same time. The repetition of "first" also implies that following the first round of violent reaction there will be other rounds. All the renderings but the one by LE ignore the word "first" and LE's rendering mistakenly changes the original meaning of the first round into the first person. As to the repeated word “violently”, SUN's rendering tries to keep the repetition formally by using two adverbs “极力” and “极为”, which share the same Chinese character “极”, but is still insufficient to retain the rhetorical and cohesive effects of the repetition employed in the original discourse. The renderings of other translators, rejecting the formal repetition in the original discourse, resort to another option and use antonyms. LE's rendering fails to convey the sharp contrast between the two possible attitudes of Mrs. Bennet for the reason that “极力反对” contains four characters and does not quite match “满心欢喜地接受”, which contains six characters. The mismatch in terms of form lessens the extents of similarity and contrast. In the renderings of FANG, WANG, and ZHANG and ZHANG, the matches are better owing to formal conformity but the contrast is still insufficient. In the rendering of LIU and DENG, the combination of “暴跳如雷地拒绝” and “欣喜欲狂地接受” best captures the contrast in terms of form and force, but creates a problem for the translation of the following part of the discourse. LIU and DENG failed to come up with another pair of perfect contrast for "the first raptures of her joy" and "the first vehemence of her disapprobation". It can be safely said that in the translation of repeated words used to compare and contrast, the translator can either keep the form of repetition or use antonyms. By putting “第一波反应” at the beginning of a sentence, the emphasis conveyed by the repetition of "first" can be somewhat maintained. My suggested rendering is as follows.

但是, 对这门婚事母亲是极度地反对也好, 还是极度地欢喜也好, 她的言谈举止都会有失体统。母 亲对婚事的第一波反应, 不管是欣喜欲狂的欢呼, 还是暴跳如雷的拒绝, 都不能让达西先生听到了, 伊 丽莎白会受不了。

Example (5)

"You look conscious. Young ladies have great penetration ${ }^{1}$ in such matters as these; but I think I may defy even your sagacity, to discover the name of your admirer. (Austen, 1949, p. 302) 
Her father had most cruelly mortified her, by what he said of Mr. Darcy's indifference, and she could do nothing but wonder at such a want of penetration, ${ }^{2}$ or fear that perhaps, instead of his seeing too little, she might have fancied too much. (Austen, 1949, p. 305)

Table 5

Translation of Repeated Word Used to Catch the Reader's Attention and Make a Contrast

\begin{tabular}{|c|c|c|c|c|c|c|}
\hline & FANG & LIU \& DENG & LE & WANG & SUN & ZHANG \& ZHANG \\
\hline penetration $^{1}$ & 洞察力 & 洞察力 & 看得透彻 & 精明 & 洞察力 & 洞察力 \\
\hline penetration $^{2}$ & 观察力 & 观察力 & ○ & 糊涂 & 眼力 & 眼力 \\
\hline
\end{tabular}

It can be clearly seen in this example that repetition of words is used to form a contrast and this contrast creates a humorous effect: Mr. Bennet feels confident about his observation that young ladies like Elizabeth have great penetration in matters of attachment and talks about it in a somewhat joking way without realizing that he is seen in the eyes of his daughter as a man in want of penetration. WANG's rendering employs antonyms, but “精明” and “糊涂”, unlike high-key four-character Chinese idioms opposite in meaning, may fail to be recognized as opposite pairs owing to the wide space (three pages apart) between the two discourses in which "penetration" occurs. Therefore, the humorous effect in the original discourse can be lost in WANG's rendering. LE's rendering mistakenly neglects the second "penetration" and the renderings of the other four translators negligently change “洞察力” into “眼力” or “观察力” and therefore blur the original contrast.

Example (6)

"You are each of you $\underline{\mathrm{so}}^{1}$ complying, that nothing will ever be resolved on; $\underline{\mathrm{so}}^{2}$ easy, that every servant will cheat you; and $\underline{s o}^{3}$ generous, that you will always exceed your income". (Austen, 1949, p. 234)

“你们两个都很随和, 因此什么事也拿不定主意。你们那么宽容, 个个佣人都要欺负你们。你们又那么慷慨, 总 要落得入不敷出”。(SUN, 1999, p. 315)

Table 6

Translation of Repeated Word Used to Prepare for Parallelism and Emotional Effects

\begin{tabular}{|c|c|c|c|c|c|c|}
\hline & FANG & LIU \& DENG & LE & WANG & SUN & ZHANG \& ZHANG \\
\hline so $^{1}$ & 那么 & $\circ$ & 那么 & o & $\circ$ & 过于 \\
\hline $\mathrm{so}^{2}$ & $\circ$ & $\circ$ & 那么 & 那么 & 那么 & 过于 \\
\hline $\mathrm{so}^{3}$ & 如此 & $\circ$ & 那么 & 那么 & 那么 & 过于 \\
\hline
\end{tabular}

In Example (6), "so" is used three times to prepare for parallelism and an emotional effect. However, only the renderings by ZHANG and ZHANG and LIU and DENG keep the repetition to a full extent. This proves that the majority of translators of the novel were not careful enough when dealing with repetition.

\section{Cross-Clausal Repetition of Words Used in Dialogues}

Repetition is used to add new information. Repetition of words is used in dialogues to join in a conversation or keep a conversation going. More specifically, repetition can be used in a conversation to agree or refute.

Example (7)

"Did not you think, Mr Darcy, that I expressed myself uncommonly well just now, when I was teasing Colonel Forster to give us a ball at Meryton?"

"It will be her turn soon to be teased", said Miss Luccas. (Austen, 1949, p. 20) 
“达西先生, 我刚才跟福斯特先生开玩笑, 要他在梅里顿开一次舞会, 难道你不觉得我的话讲得非常得体吗?”

“这下子该她受人讱笑了”, 卢卡斯小姐说道。(Sun, 2003, p. 24)

Table 7

Translation of Repeated Word Used to Join in a Conversation

\begin{tabular}{lllllll}
\hline & FANG & LIU \& DENG & LE & WANG & SUN & ZHANG \& ZHANG \\
\hline teasing & 开......玩笑 & 忩㫣 & 讲笑话 & 缠住 & 开玩笑 & 硬逼 \\
teased & 提建议 & 戏弄 & 见笑 & 缠住 & 讱笑 & 硬逼 \\
\hline
\end{tabular}

Miss Lucas' utterance is made as a well-meant suggestion that her friend Elizabeth play a tune at the piano. Here the echoing of the word "tease" shows to the source reader that Miss Lucas is a skilled speaker and knows how to join in a conversation in a humorous and smooth way, but this impression intended by the novelist is not accessible at all to some Chinese readers in Sun's rendering. “玩笑” and “讱笑” have different denotative and connotative meanings and the connection established by the original repetition is thus lost. Seeing SUN's rendering, some target readers may be inclined to draw the unwanted inference that Miss Lucas is perhaps hinting that she thinks Elizabeth's tease has achieved an unfavorable effect on Colonel Forster or that Miss Lucas's suggestion is not well-meant. Therefore SUN's rendering runs the risk of adding unwanted meanings to Lady Lucas' utterance and to the novelist's intention. Out of the six renderings only the ones by ZHANG and ZHANG and WANG keep the function of the original repetition. SUN's rendering can be improved by changing “这下子该她受人讱笑了” into “现在该别人开她的玩笑了”.

Example (8)

"How unfortunate that you should have used such very strong expressions in speaking of Wickham to Mr Darcy, for now they do appear wholly undeserved!"

"Certainly. But the misfortune of speaking with bitterness is a most natural consequence of the prejudices I had been encouraging..." ( Austen, 1949, p. 190)

“你在达西先生面前谈起威克姆的时候, 竟然对达西先生不耐烦, 这真是天大的不幸。现在看来, 威克姆不配 得到你的庇护”。

“确实如此。不过, 我虽然对他说了些刻薄的话, 造成了遗憾, 但那是我长期对他持有偏见的必然结果......” (FANG, 2011, p. 207)

Table 8

Translation of Repeated Word Used to Agree and Add New Information

\begin{tabular}{|c|c|c|c|c|c|c|}
\hline & FANG & LIU \& DENG & LE & WANG & SUN & ZHANG \& ZHANG \\
\hline unfortunate & 不幸 & 失算 & 真不幸 & 不幸 & 不幸 & 令人遗憾 \\
\hline misfortune & 遗憾 & o & o & o & 不幸 & 不幸 \\
\hline
\end{tabular}

In this example, Elizabeth keeps the conversation going by agreeing with her sister that speaking with strong expressions to Mr. Darcy is a misfortune and by adding the reason why she speaks with bitterness. The use of "misfortune" facilitates the turn-taking process in a conversation. With the help of "certainly", the determiner "the" and the obvious connection between "unfortunate" and "misfortune", the reader is able to guess what misfortune Elizabeth is referring to even without the clarifying expression "of speaking with bitterness".

Of the six renderings of the discourse, only the rendering by Sun retains the function of the English cognate by changing the original noun “misfortune” into the adverb “unfortunately" (我不幸出言刻薄). In the 
renderings of FANG and ZHANG and ZHANG, distant synonyms “不幸” and “遗憾” are used to depict the same thing and this certainly weakens the conformity between Elizabeth and Jane and lessens the cohesive effect of the original repetition. In the original discourse, Elizabeth's agreement with her sister is exhibited by “certainly” and the cognate “misfortune”. In FANG's rendering, however, it is not easy to tell whether “确实如 此” refers to the first part of Jane's comment or the second part. In other words, in FANG's rendering it is not clear whether Elizabeth agrees with Jane on the first part of her comment or the second part, for in the eyes of Jane speaking to Darcy with strong expressions is “天大的不幸” while in Elizabeth’s opinion it is just “遗憾”. Similar problems occur in the renderings of some of the other translators.

Example (9)

"How can you be so silly", cried her mother, "as to think of such a thing, in all this dirt! You will not be fit to be seen when you get there".

"I shall be very fit to see Jane, which is all I want". (Austen, 1949, p. 26)

“你怎么能这么俊”, 她母亲喊着, “这一路都是泥泞, 居然想要这么走。你到了那儿, 就没法儿见人了”。

“我见见简总可以吧一我想的就只有这件事”。(ZHANG \& ZHANG, 2004, p. 27)

Table 9

Translation of Repeated Words Used to Refute

\begin{tabular}{lll}
\hline & (not) be fit to be seen & be (very) fit to see (Jane) \\
\hline FANG & 你那副狼狈的样子怎么见人呢? & 不管模样怎么样, 我的目的是看望简 \\
LIU \& DENG & 并不适宜出现在那样的场合里 & 去看看珍是非常适宜的 \\
LE & 让人看见了不是很没面子吗? & 只要让我见到珍就成 \\
WANG & 你那副样子怎么见人? & 我只要能见到吉英就成 \\
SUN & 你那副样子就见不了人啦 & 我只要见得了简就行 \\
ZHANG \& ZHANG & 就没法儿见人了 & 我见见简总可以吧 \\
\hline
\end{tabular}

In this example, the repetition of "fit to be seen" fulfills the function of refutation and the word "very" produces a strong tone of refutation. The discourse shows a strong affection between the two sisters: Jane and Elizabeth are fit to see each other under any circumstances. To achieve faithfulness in translation, the meaning and tone of Elizabeth's reply need to be retained. Of all the six renderings of the discourse, none fully achieves that faithfulness. The rendering of ZHANG and ZHANG, for example, is likely to give the reader the impression that Elizabeth is negotiating. Improvement can be made to the renderings of WANG, SUN, and LIU and DENG. See the improvement below.

“你那副样子怎么见人”。

“见吉英怎么不行? 能见到吉英就足够了”。

“......等你到了那里, 你那副样子就见不了人啦”

“但绝对见得了简。这就足够了”。

“......你并不适宜出现在那样的场合里”。

“但绝对适宜看看珍。能见到珍就足够了”。

Example (10)

"Miss Eliza Bennet", said Miss Bingley, "despises cards. She is a great reader and has no pleasure ${ }^{1}$ in anything else".

"I deserve neither such praise nor such censure", cried Elizabeth; "I am not a great reader, and I have pleasure ${ }^{2}$ in many things". 
"In nursing your sister I am sure you have pleasure ${ }^{3}$, said Bingley; "and I hope $\underline{i t}^{4}$ will soon be increased by seeing her quite well" (Austen, 1949, p. 30)

“伊莱莎. 本内特小姐看不起玩牌”, 宾利小姐说。“她是个了不起的读书人, 对别的任何事情都没兴趣”。

“我不是什么了不起的读书人，再说我对许多事情都有兴趣”。

“看护你姐姐, 我相信你一定高兴”, 宾利说, “而且我想, 你要是看到她病体康复, 一定会更高兴”。 (ZHANG, 2004, p. 31)

Table 10

Translation of Repeated Word Used to Refute, Agree, and Retain the Theme of a Discourse

\begin{tabular}{|c|c|c|c|c|c|c|}
\hline & FANG & LIU \& DENG & $\mathrm{LE}$ & WANG & SUN & ZHANG \& ZHANG \\
\hline (has no) pleasure ${ }^{1}$ & (不感)兴趣 & (没什么) 兴趣 & (毫无) 兴趣 & $\begin{array}{l}\text { (都不感到) } \\
\text { 乐趣 }\end{array}$ & (不感) 兴趣 & （没）兴趣 \\
\hline (have) pleasure $^{2}$ & 感兴趣 & (有高度) 兴趣 & (感) 兴趣 & (感到) 乐趣 & (感) 兴趣 & (有) 兴趣 \\
\hline pleasure $^{3}$ & $\begin{array}{l}\text { (对你姐姐的身 } \\
\text { 体) 感兴趣 }\end{array}$ & 乐意 & 乐意 & 乐意 & $\begin{array}{l}\text { (毫无疑问, } \\
\text { 你就很)乐意 }\end{array}$ & 高兴 \\
\hline $\mathrm{it}^{4}$ & 轻松愉快 & 高兴 & 快活 & 快乐 & 快乐 & 高兴 \\
\hline
\end{tabular}

Sometimes in one discourse more than one function of repetition can be found. In this example, Elizabeth joins in the conversation to refute and Bingley to confirm what Elizabeth has said and then add more information. In this discourse the word "pleasure" is repeated several times. The repetition of "pleasure" also serves the function of retaining the theme of the discourse. As can be seen from the table above, none of the six renderings of the discourse succeeds in using one Chinese equivalent of "pleasure" that fits the whole discourse. It is worth mentioning, however, that some renderings employ varied techniques to try to establish cross-clausal connection. The renderings of WANG and ZHANG and ZHANG make use of partial sameness of characters to create connection and the rendering of SUN adds confirmative expression “就” to convey agreement. FANG's rendering can be improved by changing “对你姐姐的身体感兴趣” into “对照顾你姐姐感兴趣”. While it is true that very often translators come across problems that seem unsolvable, in this example improvement can be made in the translation of "pleasure".

(1) “......别的任何事儿都不能给她带来乐趣”。

“......很多事儿都能给我带来乐趣”。

“照顾你姐姐, 毫无疑问给你带来乐趣, 但愿她早点复元, 那你就会更加快乐了”。

(2) “......别的任何事儿都不能给她快乐”。

“......很多事情都能给我快乐”。

“毫无疑问, 看护你姐姐就能给你快乐/看护你姐姐就让你很快乐。但愿她早点复元, 这样你就会更 加快乐了”。

From the examples above we can conclude that the repetition of words cross clauses are very likely to create problems for translators for several reasons. Firstly, as shown by Example (1) and Example (5), cross-clausal repetition is sometimes not easily recognizable owing to the extended textual space between the repeated words. Secondly, as shown in Example (10) in cross-clausal repetition the word may be repeated many times in different clauses and this increases difficulty for translators to find an equivalent that fits throughout the discourse as more clauses mean a more complicated situation.

As can be seen from the analysis of the ten examples, the functions of cross-clausal repetition were not fully valued by the majority of the translators. Example (6) proves that sometimes the translators were not 
carefully enough when handling repetition for only two renderings out of six faithfully retain the repetition of "so". In Example (8), only SUN faithfully retained the repetition of "unfortunate". In fact, the functions of repetition in these two examples could have been easily maintained by the translators. The rates of satisfying and acceptable renderings in the 10 examples are low and there is no improvement over the years in the quality of translation regarding repeated words. The following table shows a clear picture of how the translators performed.

Table 11

Rates of Satisfying and Acceptable Renderings

\begin{tabular}{|c|c|c|c|c|c|c|c|c|c|c|}
\hline & 1 & 2 & 3 & 4 & 5 & 6 & 7 & 8 & 9 & 10 \\
\hline FANG & & & & \pm & & & & & & \\
\hline LIU \& DENG & & & \pm & & & & & & \pm & \\
\hline LE & & \pm & & & & + & & & & \\
\hline WANG & & \pm & \pm & & & & + & & & \pm \\
\hline SUN & & & \pm & \pm & & & & + & & \\
\hline ZHANG \& ZHANG & & & \pm & & & + & + & & & \pm \\
\hline
\end{tabular}

Altogether the translators scored $11 \pm( \pm$ represents acceptable rendering $)$ and $5+(+$ represents satisfying rendering) out of $60+(6 \times 10)$. The rates of satisfying and acceptable renderings of repeated words are $8.3 \%$ and $18.3 \%$ respectively. FANG, LIU and DENG, and LE, whose versions of the novel came out later after those of the other translators were published, scored $4 \pm$ and $1+$ while the other translators scored $7 \pm$ and $4+$. Of all the translators, ZHANG and ZHANG performed the best, scoring $2+$ and $2 \pm$, followed by WANG with $1+$ and $3 \pm$ and SUN with $1+$ and $2 \pm$. The rate of satisfying and acceptable renderings by ZHANG and ZHANG is $40 \%$.

\section{Conclusion}

This paper analyzes 10 discourses where repetition of words occurs using the principle of faithfulness in the translation of literary works and draws the conclusion that the translators in general failed to pay enough attention to the functions of repetition in their translation and that the rate of satisfying or acceptable renderings of repeated words is low. Compared with the versions by WANG, SUN, and ZHANG and ZHANG, the versions by FANG, LIU and DENG, and LE make no improvement as far as repeated words are concerned. This paper also provides alternative renderings of repeated words in the discourses whenever necessary. Besides, the efforts made by the translators to try to fulfill the functions of repetition in some of the discourses do not go unnoticed in this paper. The techniques employed by the translators include using expressions which partially share the same Chinese characters, adding intensifiers to express emphasis, and using antonyms to convey contrast. However, more examples are needed to draw a more convincing conclusion.

\section{References}

Anderson, C. (1994). Matthew's narrative web: Over, and over, and over again. Sheffield: JSOT Press.

Austen, J. (2003). Pride and prejudice. London: Planet Three Publishing Network Ltd..

Burton, G. (2007). Silva rhetoricae. Retrieved from http://rhetoric.byu.edu/

FANG, H. W. (Trans.). (2011). Pride and prejudice. Nanjing: Yilin Publishing House.

Halliday, M., \& Hasan, R. (Trans.). (2007). Cohesion in English. Beijing: Foreign Language Teaching and Research Press.

HU, Z. L. (1984). Discourse cohesion and coherence. Shanghai: Shanghai Foreign Language Education Press. 
JING, S. R. (2010). On the English-Chinese translation of repetition of rhetorical words in a discourse: A case study of four Chinese versions of "Of Innovations". Paper presented at The Ninth National Symposium of China Association for Comparative Studies of English and Chinese, Ningbo, China.

Kirby, J. (2009). Repetition in the book of revelation (Doctoral dissertation, The Catholic University of America).

LE, X. (Trans.). (2011). Pride and prejudice. Taipei: The Commercial Press Ltd..

LI, C. B. (2004). Paregmenon and its E/C translation. Foreign Language Education, 1, 56-58.

LI, X. L. (2016). On the translation of "pride" in Pride and Prejudice. US-China Foreign Language, 151, 149-156.

LIU Y. K., \& ZHANG, Z. H. (1998). A new approach on English paregmenon. Foreign Languages, 51, 50-55.

LIU, P. F., \& DENG, S. M. (Trans.). (2009). Pride and prejudice. Taichung: How Do Publishing Co., Ltd..

LUO, L. Q. (2007). Cross-sentence cohesive function of reiteration and translation. Journal of Dalian Maritime University (Social Science Edition), 6(3), 110.

SUN, Z. L. (Trans.). (1999). Pride and prejudice. Nanjing: Yilin Publishing House.

WANG, K. Y. (Trans.). (2006). Pride and prejudice. Shanghai: Shanghai Translation Publishing House.

XU, J. (2012). A critical study of literary translation. Retrieved from https://book.douban.com/reading/22985167/

ZHANG, D. L., \& LIU, R. S. (2003). The development of the theory of text cohesion and coherence and its applications. Shanghai: Shanghai Foreign Language Education Press.

ZHANG, L., \& ZHANG, Y. (Trans.). (2004). Pride and prejudice. Beijing: People's Literature Publishing House.

ZHOU, T. (2007). Coherence in literary translation: A case study of the Chinese versions of Pride and Prejudice. Journal of Changsha University, 21, 101.

ZHU, Y. S., ZHENG, L.X., \& MIAO, X. W. (2001). A contrastive study of cohesion in English and Chinese. Shanghai: Shanghai Foreign Language Education Press. 